\title{
Effect of Artificial Aging on Plane Anisotropy of 6063 Aluminium Alloy
}

\author{
S. O. Adeosun, O. I. Sekunowo, M. A. Bodude, A. A. Agbeleye, \\ S. A. Balogun, and H. O. Onovo \\ Department of Metallurgical \& Materials Engineering, University of Lagos, Akoka, Lagos, Nigeria \\ Correspondence should be addressed to S. O. Adeosun, samsonoluropo@yahoo.com
}

Received 15 December 2011; Accepted 11 January 2012

Academic Editor: P. Lukac

Copyright (C) 2012 S. O. Adeosun et al. This is an open access article distributed under the Creative Commons Attribution License, which permits unrestricted use, distribution, and reproduction in any medium, provided the original work is properly cited.

\begin{abstract}
Most aluminum profiles' production by deep-drawing and extrusion processes require certain degree of structural homogeneity because of the segregated second-phase particles in the as-cast structure. Rolled texture and directionality in properties often give rise to excessive earring, breakout, and tears. This study investigates the effect of heat treatment (artificial aging) on the anisotropic behavior of AA6063 alloy between rolling direction $\left(0^{\circ}\right)$ through $90^{\circ}$ directions. The results show significant reduction in property variability in the aged samples along the rolling direction $0^{\circ}$, and $90^{\circ}$ directions compared with the as-cast samples. This gave rise to improved \% elongation, impact toughness, and substantial reduction $(33.3 \%)$ in hardness. These results are capable of achieving huge savings in die conditioning and replacement with improved quality and sale of deep-drawn AA6063 alloy profiles for sustained profitability.
\end{abstract}

\section{Introduction}

In metal forming, texture gradients often ensued due to nonhomogeneous flow. Texture heterogeneities can also occur in other deformation modes, such as sheet rolling, wire drawing and tube extrusion. Thus, in many industrial forming processes for aluminum, mechanical loading is usually combined with some form of heat treatment such as annealing between deformation steps. This serves the purpose of mitigating substantially strain-hardening phenomenon during deformation. A particular example is the stretching of aluminum parts in a number of stages with intermediate annealing treatments. However, this heating and cooling cycle often results in time wastage and could be minimized.

The cause of work hardening during mechanical working varies in different aluminium alloy compositions.

Hardening of nonheat treatable Al-Mg alloys is due mainly to the presence of solute atoms in solid solution. In heat treatable $\mathrm{Al}-\mathrm{Mg}-\mathrm{Si}$ and $\mathrm{Al}-\mathrm{Cu}$ alloys, strengthening is determined by precipitates formed during aging treatment. For room-temperature forming, the material behaviour of aluminum sheet is completely determined by work hardening and almost independent of the strain rate [1].

Previous study showed that profiles extruded from both homogenized and unhomogenized billets did exhibit the same mechanical properties and metallurgical features [2]. Hence, the whole homogenizing process could be eliminated without compromising any of the mechanical properties. It is established that the factors that determine behaviour of aluminium alloy component are the type, amount, and distribution of second-phase particles such as $\mathrm{Al}-\mathrm{Fe}, \mathrm{Al}-\mathrm{Fe}-$ $\mathrm{Si}$, and $\mathrm{Al}-\mathrm{Fe}-\mathrm{Mn}-\mathrm{Si}$ dissolved in solution [3]. Furthermore, the phases formed depend mainly on the cooling rate and the $\mathrm{Fe} / \mathrm{Si}$ ratio in the alloy [4]. Manganese as a common addition in 6XXX alloys increases strength as finely precipitated intermetallics modifies the shape of plate-like iron phases which reduces their embrittling effect [5]. The combination of manganese with $\mathrm{Fe}, \mathrm{Si}$, and $\mathrm{Al}$ also forms $\alpha$ $\mathrm{Al}_{x}(\mathrm{Fe}, \mathrm{Mn})_{y} \mathrm{Si}_{z}$ phase that acts as nucleation sites for $\mathrm{Mg}_{2} \mathrm{Si}$ crystals, which eventually influences the alloys behavior [6].

Hence, precipitation-hardened aluminium alloys are commercially important group of materials because their mechanical properties can be modified by heat treatment. 
TABle 1: Chemical composition of Al 6063 alloy.

\begin{tabular}{lcccccccccc}
\hline Element & $\mathrm{Al}$ & $\mathrm{Mg}$ & $\mathrm{Si}$ & $\mathrm{Fe}$ & $\mathrm{Mn}$ & $\mathrm{Ti}$ & $\mathrm{Zn}$ & $\mathrm{Ni}$ & $\mathrm{Cu}$ & $\mathrm{Sn}$ \\
\hline \% Composition & 98.65 & 0.499 & 0.466 & 0.343 & 0.015 & 0.011 & 0.007 & 0.006 & 0.002 & 0.001 \\
\hline
\end{tabular}

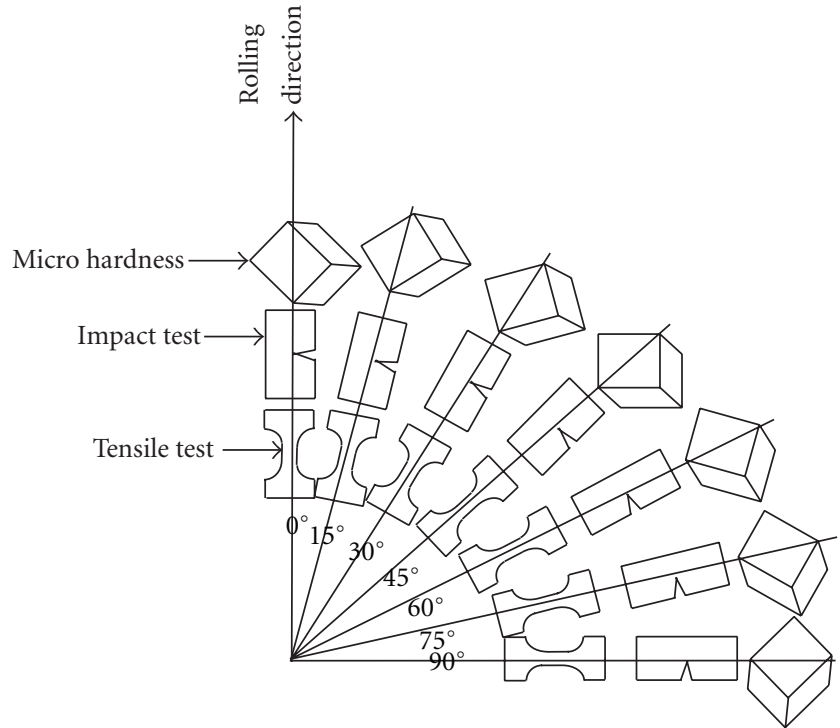

(a)

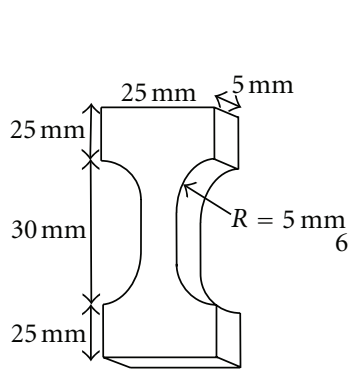

(i)

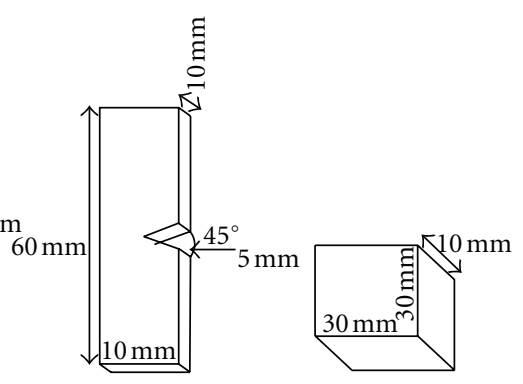

(ii) (iii) (b)

FIGURE 1: (a) Test pieces cut at different angles to the rolling direction (b) standard test samples (i) tensile, (ii) impact, and (iii) hardness.

However, the imperative of even distribution of the precipitated phases to achieve structural homogeneity is a major challenge. This paper studies the impact of ambient temperature rolling and artificial aging on the normal anisotropy, tensile strength, hardness, and impact resistance of 6063 aluminum alloy.

\section{Experimental Methodology}

The composition of AA6063 alloy used for this study is given in Table 1. Moulds for the castings were made using hardwood pattern of dimension $350 \mathrm{~mm} \times 150 \mathrm{~mm} \times 15 \mathrm{~mm}$. In the aluminum alloy, $15 \mathrm{~kg}$ was charged into a crucible and placed in a pit furnace until molten at $670^{\circ} \mathrm{C}$. The molten alloy was poured into the sand moulds and allowed to solidify.

The cleaned casts were divided into three groups, namely, control samples (CS), cold rolled sample (RS), and cold rolled and precipitation hardened sample (RAS) for further processing.

RS and RAS samples were homogenized in a Carbolite furnace at $515^{\circ} \mathrm{C}$ for 8 hours, air cooled and cold rolled (at $27.4^{\circ} \mathrm{C}$ surface temperature) to $451 \mathrm{~mm} \times 163 \mathrm{~mm}$ $\times 10 \mathrm{~mm}$ samples in 13 passes (at $34.4^{\circ} \mathrm{C}$ surface temperature) (Figure 1). Standard tensile test pieces were machined (ASTM (E8)) from CS, RS, and RAS samples at $0^{\circ}, 15^{\circ}, 30^{\circ}$, $45^{\circ}, 60^{\circ}, 75^{\circ}$, and $90^{\circ}$ directions using the rolling direction as datum line. Similarly standard, impact, and hardness tests pieces were machined (Figure 1).

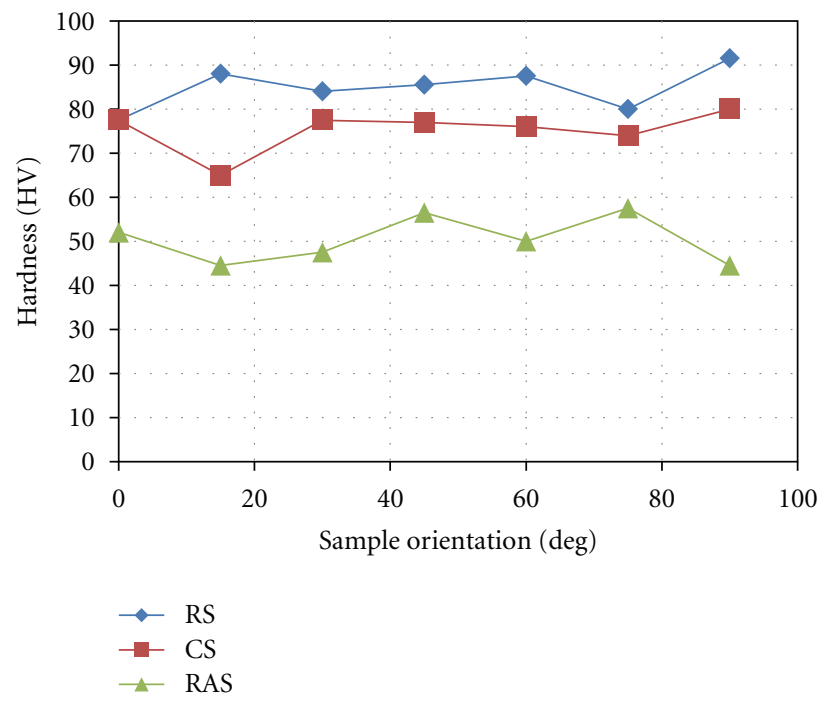

FIgURE 2: Hardness variations across sample surface.

RAS test pieces were subjected to solution heat treatment at $515^{\circ} \mathrm{C}$ for 8 hours and furnace cooled. These solutionized pieces were artificially aged at $190^{\circ} \mathrm{C}$ for 8 hours and air cooled to room temperature. Standard microstructural test pieces from CS, RS, and RAS were ground using emery paper with grit 220 to 600 microns in succession. The ground surfaces of the pieces were polished using a mixture of $\mathrm{Al}_{2} \mathrm{O}_{3}$ 


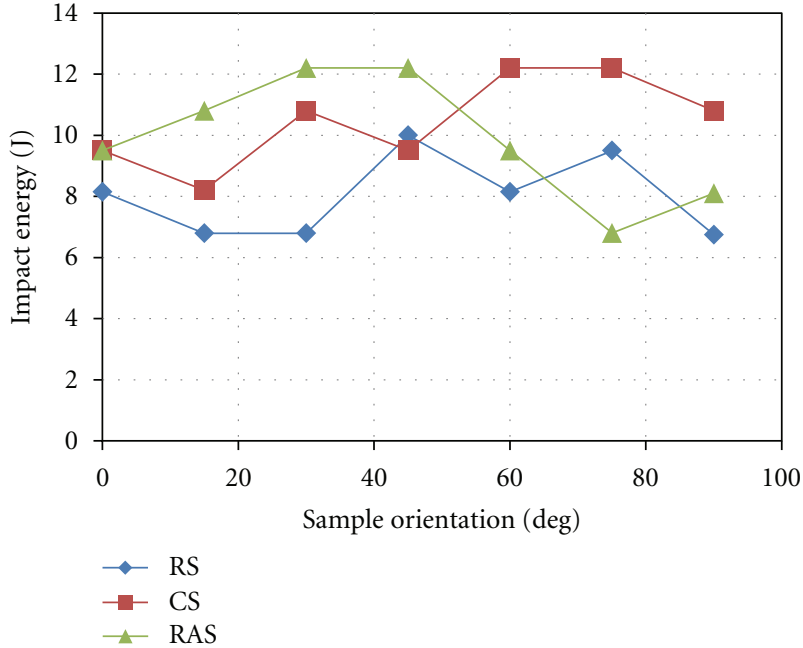

FIGURE 3: Impact energy variations across sample surface.

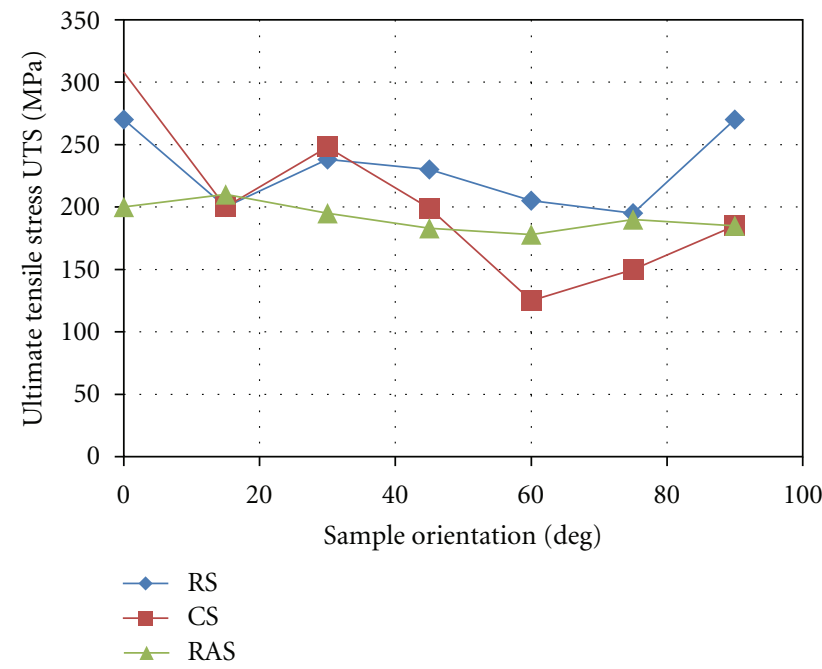

FIgURE 4: Ultimate tensile stress (UTS) variations across sample surface.

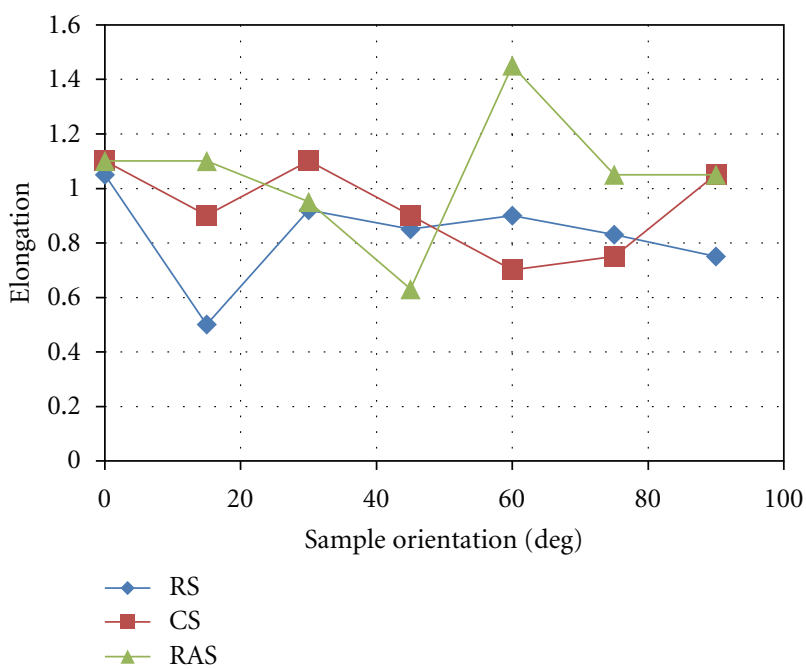

Figure 5: Elongation variations across sample surface.

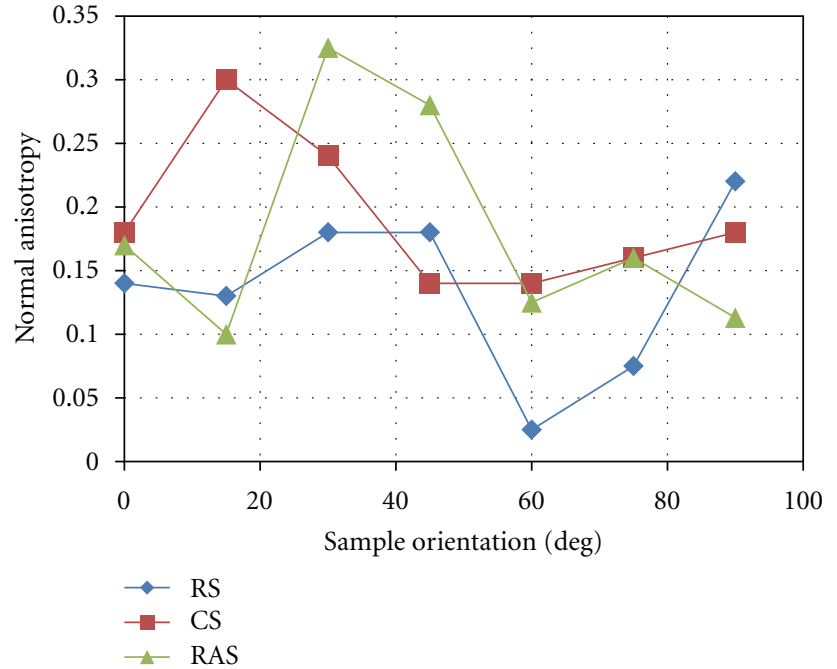

FIGURE 6: Normal anisotropy variations across sample surface.

and diamond paste before been etched a solution containing 5 grammes of sodium hydroxide $(\mathrm{NaOH})$ dissolved in $100 \mathrm{~mL}$ of water, for 20 seconds and dried. The etched surfaces crystals morphology was carried out using a Digital Metallurgical Microscope at $\times 800$ magnification, and the photomicrographs are shown in Figures 7(a)-7(i).

There were 21 samples each for tensile, hardness, and impact tests for the three categories of cast samples. A Vickers microhardness tester model "Deco" 2005 with a test load of $100 \mathrm{~g}$ and a dwell time of $10 \mathrm{~s}$ was used for the test pieces' hardness determination. Avery Impact Testing Machine (Charpy Tester) model type number 6703 and serial number E67424/4 with a striking velocity of $298.1 \mathrm{~J} / \mathrm{s}$ was used for impact energy absorption capacity of the test pieces.

\section{Results and Discussion}

In the aged sample, the hardness in the rolling direction is $51.5 \mathrm{HV}$ which is higher than at $15^{\circ}, 30^{\circ}, 60^{\circ}$, and $90^{\circ}$ directions but lower to that at $45^{\circ}(56 \mathrm{HV})$ and $75^{\circ}(57.1 \mathrm{HV})$ directions. Hardness at $45^{\circ}$ and $75^{\circ}$ directions is similar in as-cast sample, but in the rolling direction it is $77.1 \mathrm{HV}$.

However, the as-cast hardness value declined at $15^{\circ}(64.5$ $\mathrm{HV}$ ) but increased again at $30^{\circ}(78.1 \mathrm{HV})$ and remain almost the same at $45^{\circ}(76.2 \mathrm{HV}), 60^{\circ}(75.1 \mathrm{HV})$ and $75^{\circ}(72.3$ HV) respectively. Thus, peak hardness for as-cast sample is attained in the direction perpendicular to rolling direction. The rolled sample has $76.8 \mathrm{HV}$ in the rolling direction and maximum of $91.1 \mathrm{HV}$ in the $90^{\circ}$ direction.

The hardness of rolled sample is superior to as-cast sample in all directions except in the rolling direction where both samples have similar and comparable hardness response (Figure 2). Hardness across the surface for as-cast and cold rolled samples varied considerably at $20 \%$ and $15 \%$, respectively. The process of aging the as-cast structure of 6063 aluminum alloy considerably reduced its hardness by about $33.3 \%$, and this paved way for improved formability. 


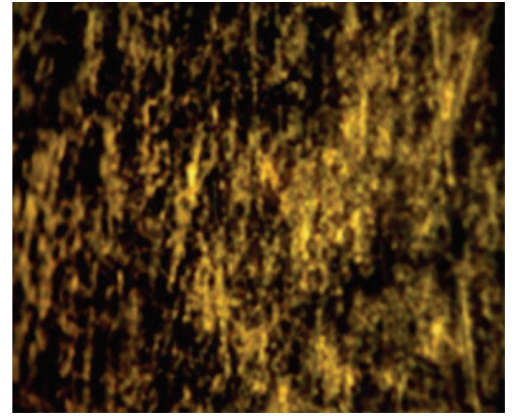

(a)

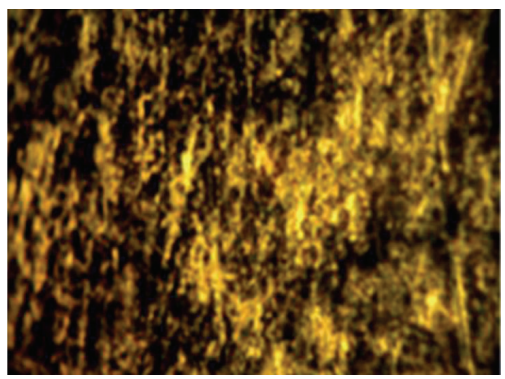

(d)

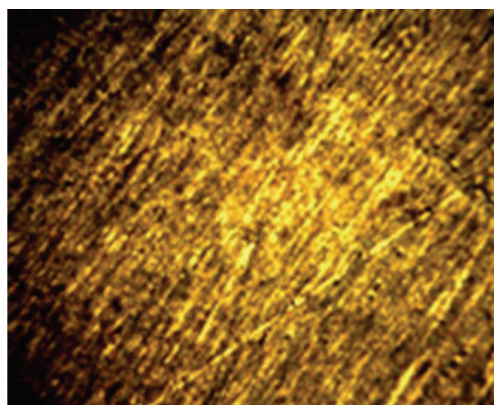

(g)

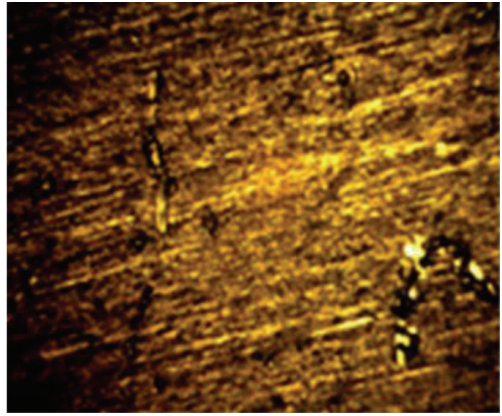

(b)

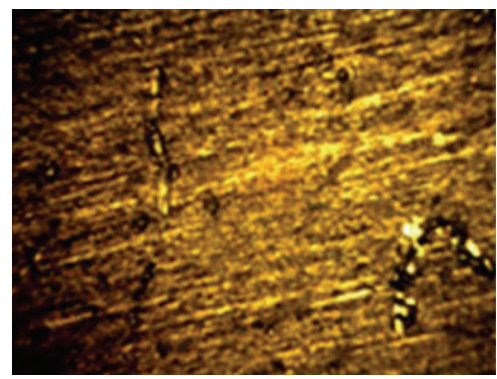

(e)

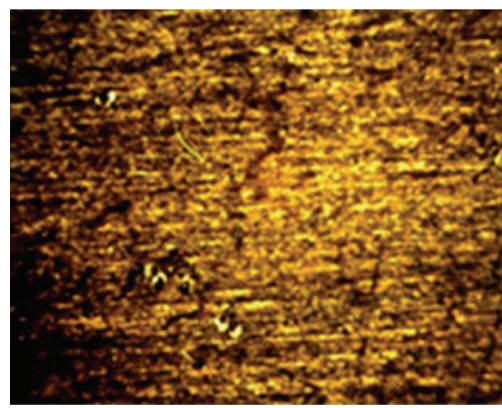

(h)

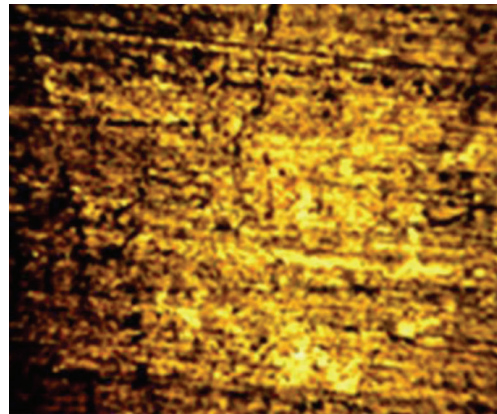

(c)

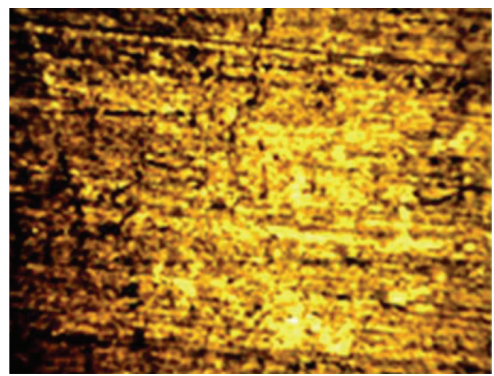

(f)

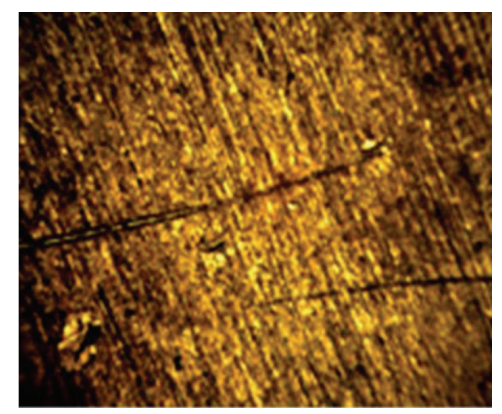

(i)

Figure 7: Micrographs of samples (a) as-cast at $0^{\circ},(\mathrm{b})$ rolled at $0^{\circ},(\mathrm{c})$ rolled and precipitation Hardened at $0^{\circ},(\mathrm{d})$ as-cast at $45^{\circ},(\mathrm{e})$ rolled at $45^{\circ}$, (f) rolled and precipitation Hardened at $45^{\circ},(\mathrm{g})$ as-cast at $90^{\circ}$, and (h) rolled at $90^{\circ}$ (i) rolled and precipitation hardened at $90^{\circ}$.

The impact energy resistances of the samples show sinusoidal pattern (Figure 3 ). The as-cast sample has minimum impact energy absorption $(8.1 \mathrm{~J})$ at $15^{\circ}$ and maximum of $12.3 \mathrm{~J}$ at $60^{\circ}$ and $75^{\circ}$ directions. Rolled sample has $6.8 \mathrm{~J}$ at $15^{\circ}, 30^{\circ}$, and $90^{\circ}$ directions which is less to that in rolling $(8 \mathrm{~J}), 45^{\circ}$, and $75^{\circ}$ directions $(9.5 \mathrm{~J})$. For the aged sample, a minimum energy absorption capacity of $6.8 \mathrm{~J}$ occurred at $75^{\circ}$ direction and maximum of $12.2 \mathrm{~J}$ at $30^{\circ}$ and $45^{\circ}$ directions. Minimal variation in impact toughness behaviour of test samples is observed. This is because the preponderance and the texture of $\mathrm{AlFeSi}$, and other toughness promoting intermetallic phases present do not differ appreciably across the sample surface.

The tensile strength of as-cast sample is maximum (305 MPa) in the rolling direction and $125 \mathrm{MPa}$ minimum at $60^{\circ}$ direction. Tensile strength of $270 \mathrm{MPa}$ is obtained in the rolled sample both in the rolling and $90^{\circ}$ directions. The tensile strength of the aged sample oscillates between
$210 \mathrm{MPa}$ and $180 \mathrm{MPa}$ with peak and minimum strengths at $15^{\circ}$ and $60^{\circ}$ directions, respectively (Figure 4 ). The elongations of the samples are similar (1.15) in the rolling direction and are better to that in other directions in as-cast and rolled samples. In the $60^{\circ}$ direction, the elongation of aged sample is 1.4 (Figure 5).

In the rolling direction, the normal anisotropy of the samples displayed close responses as the values lie between 0.14 and 0.17 . The maximum normal anisotropy for as-cast sample is 0.3 at $15^{\circ}$ direction, while the sample's minimum is 0.14 at $45^{\circ}$ direction. Normal anisotropy is 0.21 in the $90^{\circ}$ direction for rolled sample and 0.03 minimum at $60^{\circ}$ direction. The aged sample has maximum normal anisotropy of 0.33 at $30^{\circ}$ direction 0.29 in $45^{\circ}$ direction (Figure 6).

In the rolling direction $\mathrm{Mg}_{2} \mathrm{Si}$ crystals are formed at the grain boundaries in $\alpha$-aluminum matrix of as-cast sample but are discontinuous threadlike feature in the rolled matrix caused by deformation process. In the aged matrix, the 
intermetallic crystals are precipitated alongside $\alpha$ - aluminum crystals in company of other intermetallics with high nominal volume fraction than in the as-cast and rolled matrixes (Figures 7(a), 7(b), and 7(c)).

At $45^{\circ}$, there is significant increase in the nominal volume fraction of $\mathrm{Mg}_{2} \mathrm{Si}$ crystals which were precipitated in tandem with the $\alpha$-aluminum crystal and other intermetallics in as-cast matrix. The cold rolled matrix showed decrease in volume of $\mathrm{Mg}_{2} \mathrm{Si}$ crystals precipitated while its crystals point in the slip direction. However, there was an increase in nominal volume fraction of $\mathrm{Mg}_{2} \mathrm{Si}$ crystals resident at the grain boundaries in aged-sample matrix than in rolled matrix (Figures 7(d), 7(e), and 7(f)).

In the as-cast matrix fairly fine crystals of $\mathrm{Mg}_{2} \mathrm{Si}$ are precipitated side by side with crystals of $\alpha$-aluminum and other intermetallics. As the as-cast sample is being rolled, there is an increase in volume clustering of $\mathrm{Mg}_{2} \mathrm{Si}$ crystals in the matrix.

However, by aging the cold rolled sample, recrystallization and precipitation of fresh $\mathrm{Mg}_{2} \mathrm{Si}$ crystals occurred in between crystals of $\alpha$-aluminum and those of other intermetallics in directional pattern (Figures $7(\mathrm{~g}), 7(\mathrm{~h})$, and $7(\mathrm{i})$ ).

Nucleation of semicoherent precipitates, $\theta^{\prime}$ and $\theta$, often occurs at elevated aging temperature [7]. The $\theta^{\prime}$ and $\theta$ precipitates were usually impenetrable obstacles to dislocations resulting in increased work hardening of the rolled sample over other samples. The precipitate spacing also changes with aging, as well as the heterogeneity of the precipitate distribution in the matrix. All these are responsible for the changes in mechanical properties observed with test samples.

\section{Conclusion}

The results of this study have shown that moderate thermal treatment and enough time allowed for recovery ensure redistribution of the $\mathrm{Mg}_{2} \mathrm{Si}$ precipitates and other intermetallics within the matrix. This phenomenon is the precursor for the improved formability, better fracture toughness, and significant reduction in hardness coupled with minimal anisotropy.

\section{Acknowledgment}

The authors are grateful to the Management and Staff of Nigerian Aluminum Extrusion (NIGALEX) Company, Oshodi, Lagos Nigeria for the provision of 6063 aluminum alloy used in this study.

\section{References}

[1] S. Kurukuri, Simulation of thermally assisted forming of aluminum sheet, Ph.D. thesis, University of Twente, Tweante, The Netherlands, 2010.

[2] G. Al-Marahleh, "Effect of heat treatment parameters on distribution and volume fraction of $\mathrm{Mg}_{2} \mathrm{Si}$ in the structural $\mathrm{Al}$ 6063 alloys," American Journal of Applied Science, vol. 3, no. 5, pp. 1819-1823, 2006.
[3] N. C. W. Kuijpers, W. H. Kool, P. T. G. Koenis, K. E. Nilsen, I. Todd, and S. Van der Zwaag, "Assessment of different techniques for quantification of $\alpha-\mathrm{Al}(\mathrm{FeMn}) \mathrm{Si}$ and $\beta-\mathrm{AlFeSi}$ intermetallics in AA 6xxx alloys," Materials Characterization, vol. 49, no. 5, pp. 409-420, 2002.

[4] R. A. Siddiqui, H. A. Abdullah, and K. R. Al-Belushi, "Influence of aging parameters on the mechanical properties of 6063 aluminium alloy," Journal of Materials Processing Technology, vol. 102, no. 1, pp. 234-240, 2000.

[5] A. K. Gupta, D. J. Lloyd, and S. A. Court, "Precipitation hardening in $\mathrm{Al}-\mathrm{Mg}-\mathrm{Si}$ alloys with and without excess $\mathrm{Si}$," $\mathrm{Ma}$ terials Science and Engineering A, vol. 316, no. 1-2, pp. 11-17, 2001.

[6] G. Sha, K. O’Reilly, B. Cantor, J. Worth, and R. Hamerton, "Growth related metastable phase selection in a $6 \mathrm{xxx}$ series wrought $\mathrm{Al}$ alloy," Materials Science and Engineering A, vol. 304-306, no. 1-2, pp. 612-616, 2001.

[7] H. Sehitoglu, T. Foglesong, and H. J. Maier, "Precipitate effects on the mechanical behavior of aluminum copper alloys," Metallurgical and Materials Transactions A, vol. 36, pp. 1-13, 2005. 

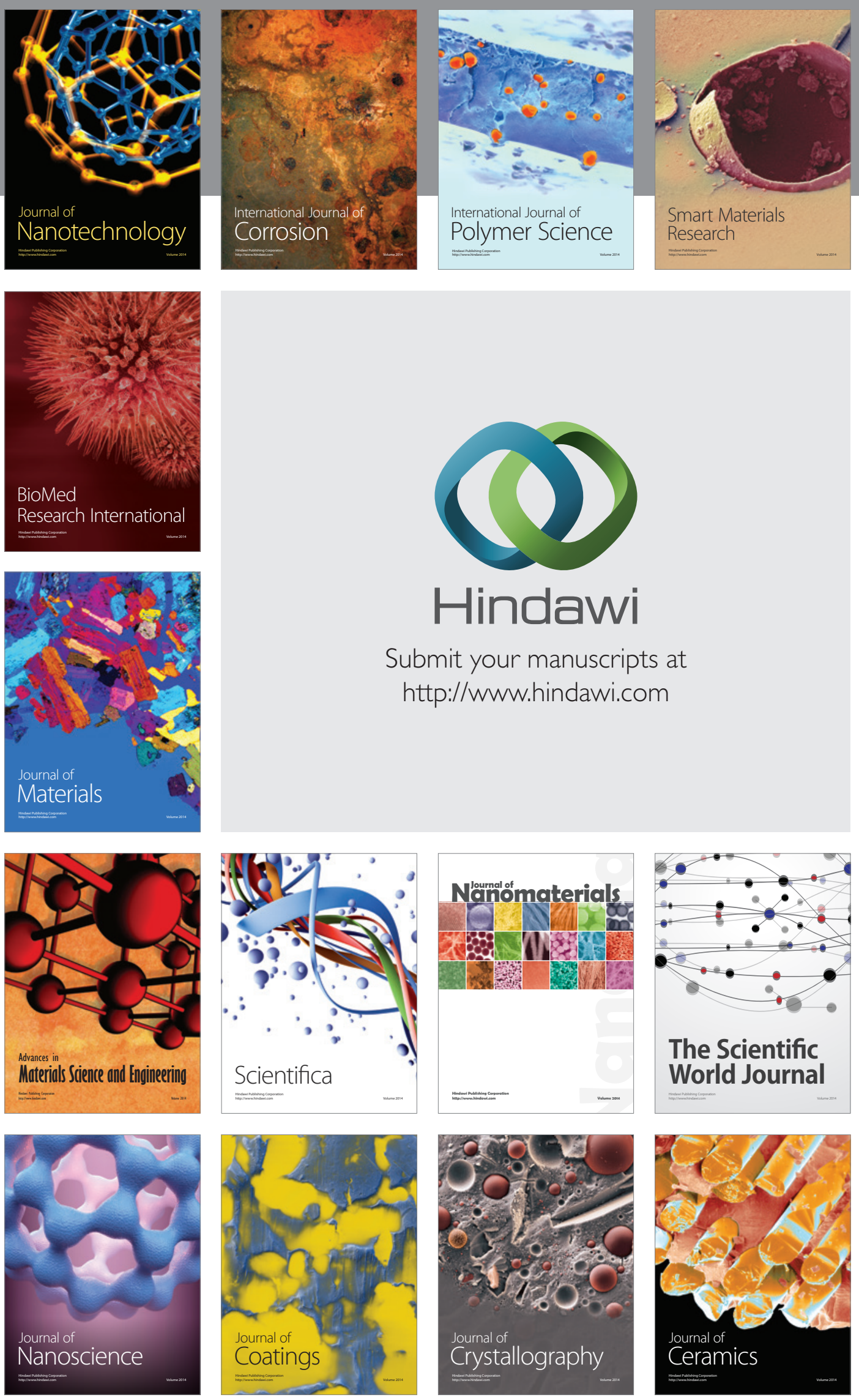

The Scientific World Journal

Submit your manuscripts at

http://www.hindawi.com

\section{World Journal}

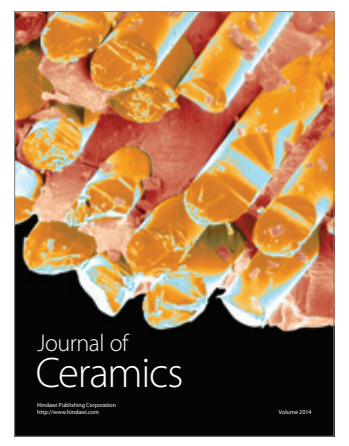

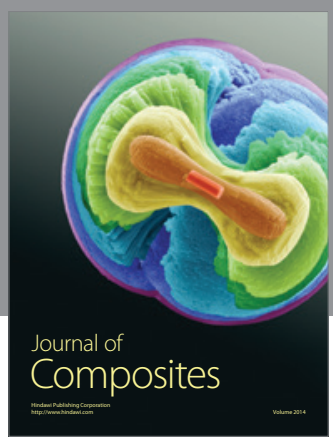
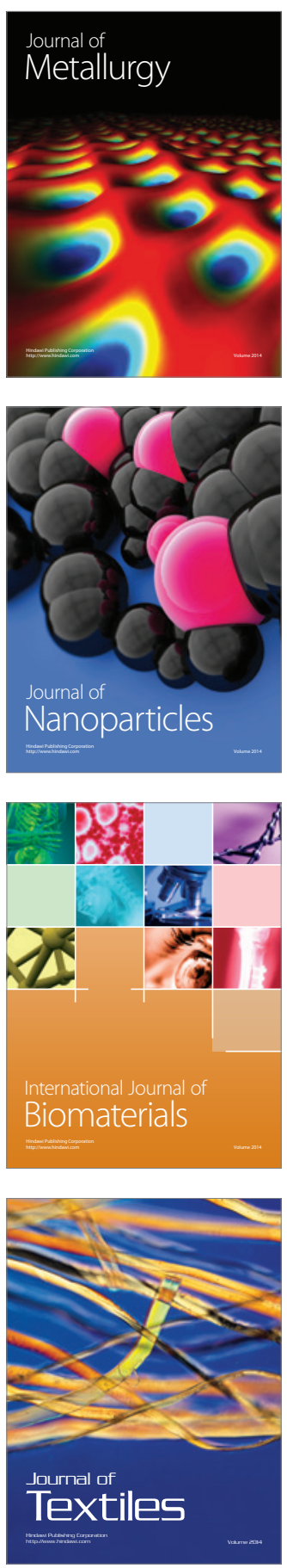